\title{
PERBEDAAN HASIL BELAJAR SISWA MENGGUNAKAN MEDIA FILM DOKUMENTER DENGAN KOMIK FOTO PADA MATA PELAJARAN AKUNTANSI KEUANGAN
}

\author{
Elsa Selviana Rahman'1, Rini Agustin Eka Yanti², Firman Aryansyah ${ }^{3}$ \\ 1,2,3 Program Studi Pendidikan Akuntansi, Univesitas Galuh, Jl, RE Martadinata No. 150, Ciamis, Indonesia \\ Email: elsaselvianarahman25@gmail.com
}

\begin{abstract}
Low student learning outcomes are a problem in this study, because learning outcomes are one of the benchmarks for the success of the learning process, educators are required to immediately seek various efforts to achieve success, low learning outcomes are motivated by various factors including the selection of learning media with the wrong type. Used by educators, as for the purpose of this study: differences in student learning outcomes in the initial measurement (prestest) and the final measurement (posttest) in the experimental class using documentary film media. Differences in student learning outcomes in the initial measurement (pretest) and final measurement (posttest) in the control class using photo comic media. Differences in student learning outcomes using documentary film media and controls using photo comic media in the experimental class and in the control class. The research method used is Quasi Experimental Design, Nonequivalent Control Group Design. Data collection techniques are carried out through tests, observation methods and documentation methods. The data analysis technique was carried out by testing the correlation product moment and then analyzing the correlation coefficient with the validity and normality tests, followed by hypothesis testing using the $t$ test formula and N-Gain. The population consisted of 34 students of class XI AKL and all of them were used as samples. Based on the results of the study, it can be concluded that there are differences in student learning outcomes in the initial measurement (pretest) and final measurement (posttest) in the experimental class using documentary film media by obtaining a fairly good average increase (significant) with its $N$-Gain of equal to 0.69 , and the control class that uses photo comics media has a significant (significant) increase in average with its N-Gain of 0.53 in the Financial Accounting subject at SMK As-Saabiq.
\end{abstract}

Keywords: Documentary Film and Photo Comics Learning Media, Learning Outcomes.

\section{ABSTRAK}

Rendahnya hasil belajar siswa merupakan masalah dalam penelitian ini, karena hasil belajar merupakan salah satu tolok ukur keberhasilan proses pembelajaran, maka pendidik dituntut untuk segera mencari berbagai upaya untuk mencapai keberhasilan, rendahnya hasil belajar dilatarbelakangi oleh berbagai faktor diantaranya pemilihan media pembelajaran dengan tipe yang tidak tepat digunakan oleh pendidik, adapun tujuan dari penelitian ini: perbedaan hasil belajar siswa pada pengukuran awal (pretest) dan pengukuran akhir (posttest) di kelas eksperimen yang menggunakan media film dokumenter. Perbedaan hasil belajar siswa pada pengukuran awal (pretest) dan pngukuran akhir (posttest) di kelas kontrol yang menggunakan media komik foto. Perbedaan hasil belajar siswa yang menggunakan media film dokumenter dan kontrol yang menggunakan media komik foto di kelas eksperimen dan di kelas kontrol. Metode penelitian yang digunakan adalah Quasi Eksperimental Design Nonequivalent Control Group Design. Teknik pengumpulan data yang dilakukan dengan melalui test, metode observasi dan metode dokumentasi. Teknik analisis data dilakukan dengan uji korelasi product moment kemudian menganalisis koefisien korelasi dengan uji validitas dan normalitas, dilajutkan dengan uji hipotesis dengan menggunakan rumus uji t dan N-Gain. Populasi terdiri dari 34 orang siswa kelas XI AKL dan semuanya digunakan sebagai sampel. Berdasarkan hasil penelitian dapat disimpulkan bahwa terdapat perbedaan hasil belajar siswa pada pengukuran awal (pretest) danpengukuran akhir (posttest) di kelas eksperimen yang menggunakan media film dokumenter dengan memperoleh peningkatan rata-rata yang cukup baik (signifikan) dengan N-Gain nya yaitu sebesar 0.69 , dan kelas kontrol yang menggunakan media komik foto dengan memperoleh peningkatan rata-rata yang cukup (signifikan) dengan N-Gain nya yaitu sebesar 0.53 pada mata pelajaran Akuntansi Keuangan di SMK As-Saabiq.

Kata Kunci: Media Pembelajaran Film Dokumenter dan Komik Foto, Hasil Belajar.

Cara sitasi: Rahman, E.,S,. Yanti, R., A., \& Aryansyah, F. (2021). Perbedaan Hasil Belajar Siswa Menggunakan Media Film Dokumenter Dengan Media Komik Pada Mata Pelajaran Akuntansi Keuangan. J-KIP (Jurnal Keguruan dan IImu Pendidikan), 2 (3), 141-152. 


\section{PENDAHULUAN}

Manusia dalam melaksanakan fungsi-fungsi kehidupan tidak bisa dilepaskan dari pendidikan, karena pendidikan berfungsi untuk meningkatkan kualitas manusia baik individu maupun kelompok, baik jasmani, rohani, spiritual, material maupun kematangan berpikir, dengan kata lain untuk meningkatkan kualitas sumber daya manusia. Proses pembelajaran berperan sangat penting dalam meningkatkan mutu pendidikan. Setiap proses pembelajaran tentunya diharapkan siswa memperoleh hasil belajar yang baik. Namun di tahun 2020 dunia dikejutkan dengan mewabahnya suatu penyakit yang disebabkan oleh sebuah virus yang dikenal dengan Covid-19 (Corona Virus Disease 2019). Penyebaran virus di Indonesia yang semakin meluas membuat pemerintah menerapkan kebijakan yang sangat ketat untuk memutus mata rantai penyebaran Covid-19. Sosial distancing (pembatasan interaksi sosial) menjadi pilihan dalam menerapkan kebijakan untuk mencegah penyebaran Covid-19. Sosial distancing dapat menghambat laju pertumbuhan dan kemajuan dari berbagai bidang, salah satunya bidang pendidikan sehingga akan berdampak pada proses pembelajaran di sekolah. Pemerintah telah menetapkan kebijakan, yaitu memindahkan proses pembelajaran dari sistem tatap muka yang sebelumnya berlangsung di sekolah menjadi pembelajaran sistem daring (dalam jaringan) / online.

Salah satu sekolah yang melakukan pembelajaran daring adalah SMK As-Saabiq di Singaparna. Selama pendemi Covid-19 pembelajaran masih berjalan lancar namun dengan metode dan media yang sangat sederhana yaitu hanya memanfaatkan aplikasi WhatsApp dan Google Classroom dan salah satunya dengan metode penugasan. Metode penugasan tentunya membuat siswa kurang dapat menerima materi dan konsep-konsep pembelajaran dengan maksimal sehingga membuat siswa kurang paham dengan materi yang diberikan oleh guru dan membuat hasil belajar siswa menurun. Sebagaimana yang menjadi standar baik atau tidaknya hasil belajar atas dasar KKM yang telah ditetapkan sebagai patokan keberhasilan proses pembelajaran. Hasil belajar siswa menunjukan kemampuan dan kualitas siswa sebagai dampak dari proses pembelajaran yang telah dilaluinya. Melton dalam Nurhasanah (2016) menyiratkan bahwa hasil belajar kompetensi siswa yang berhasil menggunakan konten, informasi, ide-ide dan alat dalam pembelajaran. Oleh karena itu "Hasil belajar dapat didefinisikan sebagai kompetensi dan keterampilan yang dimiliki siswa setelah pembelajaran" (Molstad \& Karseth, 2016). Sedangakan menurut Sudjana (2012) menyatakan bahwa: "Dalam sistem pendidikan nasional rumusan tujuan pendidikan, baik tujuan kurikulum maupun tujuan intruksional, menggunakan klasifikasi hasil belajar teori dan teori taksonomi bloom yang secara garis besar membagi menjadi tiga ranah yakni ranah kognitif, ranah afektif, dan ranah psikomotor". Namun pada kenyataanya hasil belajar yang diperoleh siswa tidak selalu baik dan sesuai harapan. Menurut Aryansyah (2021) Rendahnya prestasi belajar atau hasil belajar siswa merupakan masalah yang menjadi topik utama di Lembaga Pendidikan. Hal ini dapat tergambar dari tidak tercapainya Kriteria Ketuntasan Minimal (KKM), yaitu nilai terendah yang ditetapkan oleh pihak Lembaga Pendidikan setelah pendidik melakukan musyawarah terlebih dahulu.

Tabel 1. Rata-Rata Penilaian Pelajaran Akuntansi Semester Ganjil

Kelas XI AKL SMK As - Saabiq

Tahun Ajaran 2020/2021

\begin{tabular}{cccccccc}
\hline Kelas & $\begin{array}{c}\text { Jumlah } \\
\text { Siswa }\end{array}$ & KKM & \multicolumn{3}{c}{ Nilai } & \multicolumn{2}{c}{ Jumlah Ketuntasan Siswa } \\
\cline { 3 - 8 } & & Tertinggi & Terendah & Rata-rata & Tuntas & Tidak Tuntas \\
\hline AKL 1 & 17 & 75 & 100 & 60 & 75 & 14 & 3 \\
\hline AKL 2 & 17 & 75 & 100 & 60 & 78 & 15 & 2 \\
\hline
\end{tabular}

Sumber: SMK As-Saabiq (2020)

Berdasarkan tabel di atas dapat dilihat masih terdapat siswa yang belum memenuhi standar ketuntasan minimal yang telah ditetapkan sekolah yakni kelas XI AKL. Luas nya cakupan materi dalam pembelajaran akuntansi keuangan menuntut guru harus mampu mengembangkan sistem 
pembelajaran yang efektif dan efisien, sehingga siswa dapat lebih mudah memahami dan mengerti informasi yang disampaikan dan membuat hasil belajar siswa menjadi baik. Salah satu upaya yang dapat dilakukan dalam mengembangkan sistem pembelajaran yang efektif dan efisien selama proses pembelajaran daring, yaitu dengan menggunakan media pembelajaran.

Menurut Utama, et al. dalam Agustiany et al., (2021) mengungkapkan fungsi media dalam proses pembelajaran diantaranya, penyampaian pesan pembelajaran menjadi lebih terstandar serta dalam pembelajaran dapat lebih menarik dan lebih interaktif. Menurut Sanjaya dalam Agustiany et al., (2021) "Media audio-visual adalah media yang mempunyai unsur suara dan unsur gambar yang dapat dilihat, misalnya seperti rekaman video, slide, suara dan sebagainya".

Salah satu media pembelajaran yaitu media film dokumenter dan media komik foto mampu membantu siswa lebih aktif dalam mengikuti pembelajaran. Media film adalah media yang dipakai untuk merekam suatu keadaan, atau mengemukakan sesuatu. Film dipakai untuk mengkomunikasikan gagasan, pesan atau kenyataan. Karena keunikan dimensinya film telah diterima sebagai salah satu media audiovisual yang paling popular dan digemari karena juga dianggap sebagai media yang efektif. Indriana (2011) menyebutkan bahwa "Film sebagai media pembelajaran memiliki kelebihan yaitu film dapat memberikan pesan dan kesan yang dapat diterima oleh siswa karena film menampilkan suatu proses yang lebih mudah dipahami oleh siswa, dapat digunakan secara berulang-ulang dan tidak membuat bosan siswa dalam mengikuti pembelajaran".

Sedangkan media komik foto menurut Laurent (2018) "Peranan pokok yang terdapat dalam komik adalah menciptakan suatu kemampuan dimana seorang siswa minat dan motivasi siswa dapat tumbuh dalam setiap diri individu. Kelebihan dari komik sendiri adalah membimbing dan menumbuhkan minat baca siswa, Mempermudah siswa dalam menangkap materi yang rumusan yang abstrak".

Media pembelajaran mempunyai arti yang cukup penting, karena dalam ketidak jelasan materi yang disampaikan dapat diselesaikan dengan bantuan media pembelajaran. Berdasarkan latar belakang yang telah dipaparkan peneliti tertarik melakukan penelitian dengan judul "Perbedaan Hasil Belajar Siswa Yang Menggunakan Media Film Dokumenter Dengan Hasil Belajar Siswa Yang Menggunakan Media Komik Foto Di SMK As- Saabiq".

Berdasarkan latar belakang, maka permasalahan yang dapat diidentifikasi adalah sebagai berikut:

1. Hasil belajar siswa masih kurang optimal.

2. Kurangnya perhatian siswa terhadap materi yang disampaikan sehingga siswa mengalami kesulitan dalam memahami materi.

3. Belum optimalnya penggunaan media pembelajaran di saat pembelajaran daring akibat Covid19.

4. Pembelajaran masih terpusat pada guru sehingga membuat siswa menjadi jenuh.

5. Sarana dan prasana pembelajaran kurang lengkap.

Berdasarkan identifikasi masalah, maka rumusan masalah dalam penelitian ini adalah:

1. Apakah terdapat perbedaan hasil belajar siswa pada pengukuran awal (prestes) dan pengukuran akhir (posttest) di kelas eksperimen yang menggunakan media film dokumenter pada mata pelajaran Akuntansi keuangan di SMK As-Asaabiq?

2. Apakah terdapat perbe daan hasil belajar siswa pada pengukuran awal (pretest) dan pngukuran akhir (posttest) di kelas kontrol yang menggunakan media komik foto pada mata pelajaran Akuntansi Keuangan di SMK As-Saabiq?

3. Apakah terdapat perbedaan hasil belajar siswa pada pengukuran akhir (posttest) di kelas eksperimen yang menggunakan media film dokumenter dengan kelas kontrol yang menggunakan media komik foto pada mata pelajaran Akuntansi Keuangan di SMK As-Saabiq?

Berdasarkan rumusan masalah yang terdapat dalam penelitian ini, maka tujuan yang hendak dicapai adalah: 
1. Untuk mengetahui perbedaan hasil belajar siswa pada pengukuran awal (pretest) dan pengukuran akhir (posttest) di kelas eksperimen yang menggunakan media film dokumenter pada mata pelajaran Akuntansi Keuangan di SMK As-Saabiq.

2. Untuk mengetahui perbedaan hasil belajar siswa pada pengukuran awal (pretest) dan pngukuran akhir (posttest) di kelas kontrol yang menggunakan media komik foto pada mata pelajaran Akuntansi Keuangan di SMK As-Saabiq.

3. Untuk mengetahui perbedaan hasil belajar siswa pada pengukuran akhir (posttest) di kelas eksperimen yang menggunakan media film dokumenter dengan kelas kontrol yang menggunakan media komik foto Pada mata pelajaran Akuntansi Keuangan di SMK As-Saabiq.

Adapun manfaat dari penelitian ini adalah sebagai berikut:

Hasil penelitian ini diharapkan dapat menambah pengetahuan dalam bidang ilmu pengetahuan dan teknologi khususnya penggunaan media film dokumenter dan media komik foto terhadap hasil belajar siswa dalam pembelajaran Akuntansi Keuangan. Selain itu penelitian ini dapat bermanfaat bagi peniliti lain sebagai referensi untuk penelitian selanjutnya.

\section{METODE PENELITIAN}

Desain penelitian yang akan digunakan dalam penelitian ini adalah Quasi EksperimentalDesign Nonequivalent Control Group Design, menurut Sugiyono (2015) "Metode penelitian ekperimen merupakan metode penelitian yang digunakan untuk mencari pengaruh treatment (perlakuan) tertentu".Pola digambarkan sebagai berikut:

Tabel 2. Design Eksperimen

\begin{tabular}{cccc}
\hline Kelas & Tas awal & Treatment & Tes Akhir \\
\hline Eksperimen & $\mathrm{O}_{1}$ & $\mathrm{X}_{1}$ & $\mathrm{O}_{2}$ \\
\hline Kontrol & $\mathrm{O}_{3}$ & $\mathrm{X}_{2}$ & $\mathrm{O}_{4}$ \\
\hline (Sugiyono, 2016) & & &
\end{tabular}

Variabel dalam penelitian ini yaitu variabel independen atau variabel bebas. Untuk variabel $(X)$ adalah perbedaan media film dokumenter dan media komik foto pada mata pelajaran akuntansi keuangan di kelas XI AKL SMK As-Saabiq. Variabel dependen ini merupakan masalah yang akan dipecahkan dalam penelitian ini, sedangkan yang menjadi variabel $(Y)$ adalah hasil belajar siswa. Populasi dalam penelitian ini adalah seluruh kelas XI AKL di SMK As-Saabiq tahun ajaran 2020/2021 yang terdiri dari dua kelas dan berjumlah 34 orang. Dengan siswa laki-laki berjumlah 7 orang dan siswi perempuan berjumlah 27 orang. Adapun rinciannya adalah sebagai berikut:

Tabel 3. Populasi Siswa Kelas XI AKL di SMK As-Saabiq

\begin{tabular}{cllc}
\hline \multirow{2}{*}{ Kelas } & \multicolumn{2}{c}{ Jenis Kelamin } & \multirow{2}{*}{ Jumlah } \\
\cline { 2 - 3 } & Laki-laki & Perempuan & \\
\hline AKL 1 & 4 Orang & 13 Orang & 17 Orang \\
\hline AKL 2 & 3 Orang & 14 Orang & 17 Orang \\
\hline Sumber: SMK As-Saabiq (2021) &
\end{tabular}

Karena desain penelitian menggunakan kelompok kontrol non ekuivalen, maka penentuan sampel dilakukan dengan menggunakan teknik "Samping Jenuh". Menurut Sugiyono (2015) "Sampling jenuh adalah teknik penentuan sampel bila semua anggota populasi digunakan sebagai sampel". Berdasarkan data dari populasi di atas, maka kedua kelas tersebut akan dijadikan sebagai satu kelas eksperimen dan satu kelas kontrol. Kelas XI AKL 1 diberi media film dokumenter dan kelas XI AKL 2 diberi media komik foto.

Data yang digunakan dalam penelitian ini yaitu data primer dan data sekunder, data primer dikumpulkan secara langsung yang berakitan dengan obyek penelitian. Teknik yang digunakan 
dalam data primer yaitu dengan melaksanakan kegiatan tes hasil belajar siswa dari kegiataan pengukuran awal (pretest) dan pengukuran akhir (posttest) pada kelas eksperimen dan kelas kontrol. Sedangkan untuk data sekunder dikumpulkan dari sumber yang telah ada di SMK AsSaabiq. Dalam memperoleh data, penulis menggunakan beberapa teknik yaitu: (1) Observasi (2) Dokumentasi (3) Tes.

Dalam penelitian ini langkah-langkah yang digunakan untuk teknik analisis data adalah sebagai berikut:

1. Uji Instrumen Penelitian

a. Uji Validitas

Dilakukan untuk menunjukkan tingkat kevalidan atau suatu kesahihan instrument. Dalam penelitian ini untuk menguji uji validitas menggunakan jenis statistika korelasi product moment.

b. Uji Reliabilitas

Untuk melihat keajegan atau kekonsistenan instrument tersebut bila diberikan pada subjek yang sama meskipun oleh orang berbeda. Dalam mencari reliabilitas penelitian ini menggunakan rumus Kuder dan Richardson ke-20 (KR-20).

c. Uji Indeks Kesukaran

Indeks kesukaran dilakukan untuk mengetahui sejauh mana butir soal tersebut dapat digunakan dalam pengujian tes dan utnuk mengetahu soal tergolong mudah atau sukar.

d. Uji Analisis Daya Beda

Mengkaji butir-butir soal untuk membedakan antara siswa yang pandai (berkemamuan tinggi) dengan siswa yang kurang (berkemampuan rendah). Dalam penelitian ini menggunakan rumus untuk indeks diskriminasi untuk menentukan uji analisis daya beda.

2. Uji Prasyarat Analisis Data

a. Uji Homogenitas

Di bawah ini merupakan langkah-langkah yang dilakukan dalam uji homogenitas:

1) Membuat tabel persiapan perhitungan perbedaan antara (pretest) kelas eksperimen dan (pretest) kelas kontrol.

2) Menetukan mean atau niali rata-rata.

3) Menentukan simpangan baku.

4) Menentukan nilai thitung dengan menggunakan t-test.

5) Menentukan derajat kebebasan (dk)

6) Mencari nilai tabel

7) Membandingkan thitung dengan $t_{\text {tabel }}$ dengan kriteria dalam pengujian.

b. Uji Normalitas

Salah satu uji prasyarat untuk memenuhi asumsi kenormalan dalam analisis data, untuk menghitung uji normalitas menggunakan rumus Uji Liliefors.

3. Uji Analisis Data

Uji analisis data ini dilakukan untuk:

a. Untuk mengetahui perbedaan hasil belajar siswa yang menggunakan media film dokumenter pada pengukuran awal (pretest) dan pengukuran akhir (posttest) di kelas eksperimen.

b. Untuk mengetahui perbedaan hasil belajar siswa yang menggunakan media komik foto pada pengukuran awal (pretest) dan pengukuran akhir (posttest) di kelas Kontrol.

c. Untuk mengetahui perbedaan hasil belajar siswa yang menggunakan media film dokumenter dan media komik foto pada pengukuran akhir (posttest) di kelas eksperimen dan kelas kontrol.

Langkah - langkah yang harus dilakukan:

1) Membuat tabel persiapan perhitungan

2) Menetukan mean atau niali rata-rata.

3) Menentukan simpangan baku. 
4) Menentukan nilai thitung dengan menggunakan t-test.

5) Menentukan derajat kebebasan (dk)

6) Mencari nilai tabel

7) Membandingkan thitung dengan tabel dengan kriteria dalam pengujian.

\section{HASIL PENELITIAN DAN PEMBAHASAN Hasil Penelitian}

Analisis data kuantitatif dalam penelitian ini digunakan untuk menjabarkan hasil penelitian dalam bentuk perhitungan angka yang mana diterapkan dengan menggunakan rumus-rumus statistik. Analisis data kuantitatif yang digunakan dalam penelitian ini adalah analisis Korelasi Product Moment.Analisis Korelasi Product Moment digunakan untuk mengetahui derajat atau kekuatan hubungan antara variabel X (Media Film Dokumenter dan Komik Foto) dengan variabel $Y$ (Hasil Belajar Siswa).

Berdasarkan hasil penelitian, deskripsi perbedaan hasil belajar siswa yang menggunakan media film dokumenter dan komik foto pada pengukuran awal (pretest) dan pengukuran akhir (posttest), di kelas eksperimen diperoleh data sebagai berikut:

Tabel 4. Rekapitulasi Hasil Pretest dan Posttest Kelas Eksperimen

\begin{tabular}{cccc}
\hline Keterangan & Prestest & Posttest & Gain \\
\hline Jumlah Sampel & 17 & 17 & 17 \\
\hline Nilai Tertinggi & 64,29 & 92,86 & 64,29 \\
\hline Nilai Terendah & 21,43 & 71,43 & 14,28 \\
\hline Nilai Rata-rata & 42,86 & 83,19 & 40,33
\end{tabular}

Sumber data diolah oleh peneliti, (2021).

Berdasarkan tabel diatas diperoleh data pada pengukuran awal (pretest) kelas eksperimen dengan jumlah sampel 17 orang siswa, nilai tertinggi sebesar 64.29 dan nilai terendah sebesar 21.43, sedangkan untuk rata-rata diperoleh sebesar 42.86. Kemudian pada pengukuran akhir (posttest) dengan jumlah sampel 17 orang siswa diperoleh nilai tertinggi sebesar 92.86, dan nilai terendah sebesar 71.43, sedangkan ntuk rata-ratanya diperoleh sebesar 83.19. Dan untuk Gain dengan jumlah sampel 17 orang siswa, nilai gain tertingi 64.29 , dan nilai terendahnya 14.28 , sedangkan nialai rata-ratanya 40.33 .

Berdasarkan hasil penelitian, deskripsi perbedaan hasil belajar siswa yang menggunakan media film dokumenter dan komik foto pada pengukuran awal (pretest) dan pengukuran akhir (posttest), di kelas kontrol diperoleh data sebagai berikut:

Tabel 5. Rekapitulasi Hasil Pretest dan Posttest Kelas Kontrol

\begin{tabular}{cccc}
\hline Keterangan & Pretest & Posttest & Gain \\
\hline Jumlah Sampel & 17 & 17 & 17 \\
\hline Nilai Tertinggi & 64,29 & 92,86 & 71,43 \\
\hline Nilai Terendah & 21,43 & 64,29 & 7,14 \\
\hline Nilai Rata-rata & 44,54 & 76,05 & 31,52 \\
\hline
\end{tabular}

Sumber: data diolah oleh peneliti, (2021)

Berdasarkan tabel diatas diperoleh data pada pengukuran awal (pretest) kelas kontrol dengan jumlah sampel 17 orang siswa, nilai tertinggi sebesar 64.29 dan nilai terendah sebesar 21.43, sedangkan untuk rata-rata diperoleh sebesar 44.54. Kemudian pada pengukuran akhir (posttest) dengan jumlah sampel 17 orang siswa diperoleh nilai tertinggi sebesar 92.86, dan nilai terendah sebesar 64.29, sedangkan untuk rata-ratanya diperoleh sebesar 76,05. Dan untuk Gain dengan 
jumlah sampel 17 orang siswa, nilai gain tertingi 71.43 , dan nilai terendahnya 7.14 , sedangkan nilai rata-ratanya 31.52 .

Tabel 6. Rekapitulasi Hasil perhitungan Uji hipotesis

\begin{tabular}{cccc}
\hline Hipotesis & $t_{\text {hitung }}$ & $t_{\text {tabel }}$ & Hasil Analisis \\
\hline 1) & 11.62 & 2.04 & $11.62>2.04$ \\
\hline 2$)$ & 8.47 & 2.04 & $8.47>2.04$ \\
\hline 3$)$ & 2.41 & 2.04 & $2.41>2.04$ \\
\hline
\end{tabular}

Sumber: data diolah oleh peneliti, (2021)

Berdasarkan di atas, dapat disimpulkan bahwa $t_{\text {hitung }}>$ dari $t_{\text {tabel, }}$ yang berarti Ha diterima dan Ho ditolak artinya terdapat perbedaan hasil belajar siswa yang menggunakan Media Film Dokumenter dan media komik foto pada pengukuran awal (pretest) dan pengukuran akhir (posttest) di kelas XI AKL di SMK As-saabiq.

\section{Pembahasan}

\section{Perbedaan Hasil Belajar Siswa yang Menggunakan Media Film Dokumenter pada Pengukuran Awal (Pretest) dan Pengukuran Akhir (Posttest).}

Berdasarkan hasil perhitungan uji statistik, diketahui bahwa terdapat perbedaan yang signifikan hasil belajar siswa yang menggunakan Media Film Dokumenter pada pengukuran awal (pretest) dan pengukuran akhir (posttest) di kelas eksperimen, Perbedaan tersebut dapat dilihat dari hasil rata-rata. Pada pengukuran awal (pretest) siswa memperoleh nilai rata-rata 42.86 dan pada pengukuran akhir (posttest) diperoleh sebesar 83.19. Dengan demikian terdapat perbedaan yang signifikan dengan $\mathrm{N}$-Gain 0,69 berkategori sedang. Perbedaan nilai rata-rata di kelas eksperimen membuktikan bahwa pengukuran akhir (posttest) yang dilakukan setelah pembelajaran dengan menggunakan Media Film Dokumenter lebih besar. Artinya bahwa Media Film Dokumenter sangat tepat digunakan pada Mata Pelajaran Akuntansi Keuangan Kompetensi Dasar Pencatatan Kartu Utang. Hal ini dikarenakan Media Film Dokumenter menurut Indriana (2011) menyebutkan bahwa film sebagai media pembelajaran memiliki beberapa kelebihan antara lain:

a. Film dapat memberikan pesan dan kesan yang dapat diterima oleh siswa karena film menampilkan suatu proses yang lebih mudah dipahami oleh siswa

b. Film dapat digunakan secara berulang-ulang dan mengatasi keterbatasan ruang dan waktu,

c. Film dapat memberikan hiburan yang berbeda kepada siswa. Hiburan itu membuat siswa tidak bosan dalam mengikuti pembelajaran.

Penerapan Media Film Dokumenter belum sepenuhnya maksimal, karena masih terdapat beberapa kendala dilapangan, diantaranya yaitu manajemen waktu dan sarana prasarana yang harus memadai. Media Film merupakan media yang bertujuan untuk meningkatkan keaktifan siswa dalam menggali dan memperdalam materi yang telah disampaikan melalui tayangan, dan materi dalam film bisa dilihat kembali atau dipelajari secara individu atau kelompok yang tidak hanya bisa dilihat di sekolah saja melainkan di tempat-tempat lain.

Hasil pengujian ini sejalan dengan penelitian terdahulu, yaitu hasil penelitian (Putro \& Tuasikal, 2018) yaitu Implementasi Media Audio visual (Video) Dan Media Gambar (Poster) Terhadap Hasil Belajar Shooting Bola basket. Dengan diperoleh adanya pengaruh yang signifikan dengan hasil uji t yaitu untuk aspek pengetahuan media gambar $4.694<2.042$ dan aspek keterampilan $9.544<2.042$ berarti ada pengaruh yang signifikan. Untuk aspek pengetahuan media video $9.604<2.042$ dan aspek keterampilan media video $7.693<2.042$ berarti ada pengaruh yang signifikan

Sedangkan perbedaan antara penelitian ini dengan penelitian (Putro \& Tuasikal, 2018) terletak dalam pengambilan sampel yaitu menggunakan teknik cluster random sampling, sedangkan penelitian ini menggunakan teknik Sampling Jenuh. Selain itu juga terdapat perbedaan yang 
mendasar dalam objek penelitian dan periode pengamatan antara keduanya, yaitu melakukan penelitian di tahun 2018 dengan objek penelitian pada kelas XI IPA pada hasil belajar shooting bola basket sedangkan penelitian ini dilakukan pada tahun 2021 dengan objek penelitian hasil belajar pada akuntansi keuangan.

\section{Perbedaan Hasil Belajar Siswa Yang Menggunakan Media Komik Foto Pada Pengukuran Awal (Pretest) dan Pengukuran Akhir (Posttest).}

Berdasarkan perhitungan uji statistik, diketahui bahwa terdapat perbedaan hasil belajar siswa yang signifikan dengan menggunakan media komik foto di kelas kontrol pada pengukuran awal (pretest) dan pengukuran akhir (posttest). Hal tersebut dapat dilihat dari rata-rata nilai pada pengukuran awal (pretest) sebesar 44.54 dan pada pengukuran akhir (posttest) sebesar 76.05. Hasil tersebut menunjukkan bahwa terdapat perbedaan hasil belajar siswa yang signifikan dengan N-Gain sebesar 0,53 . Peningkatan nilai rata-rata yang diperoleh siswa dengan menggunakan media komik foto kurang maksimal, karena peningkatan hasil belajar siswa pada Kompetensi Dasar Pencatatan Kartu Utang, termasuk ke dalam kategori Sedang.Hal tersebut disebabkan oleh beberapa faktor, sesuai dengan yang dikemukakan oleh Laurent (2018) Dalam komik juga terdapat kelemahan yang ada yaitu, sebagai berikut:

a. Komik membatasi imajinasi karena komik menyajikan gambar yang langsung dilihat tanpa harus membayangkan tokoh, tempat yanga dan pada alur cerita yang di tulis di komik.

b. Tidak mampu mengekspresikan karya seni.

c. Menimbulkan efek ketagihan pada penggunaan komik.

d. Lebih explicit dalam menggambarkan suatu adegan.

e. Terlalu sederhana bergaya visual.

Upaya untuk meningkatkan hasil belajar siswa yang menggunakan Media Komik Foto dapat dilakukan dengan cara menyampaikan materi pembelajaran dengan cara yang menarik meskipun pembelajaran tetap berorientasi pada guru, serta memberikan kesempatan lebih kepada siswa untuk menanyakan materi yang belum dipahami.

Hasil pengujian ini sejalan dengan penelitian terdahulu, yaitu hasil penelitian yang dilakukan oleh Kusnida, Mulyani \& Su'udi, (2015) tentang Keefektifan penggunaan media audio visual dan media komik strip dalam pembelajaran menulis cerpen yang bermuatan nilai-nilai karakter berdasarkan gaya belajar. Hasil penelitian yaitu perbedaan keefektifan antara penggunan media dan gaya belajar siswa yaitu pada media audio visual memberikan pengaruh besar $22,4 \%$ sedangkan dengan media komik strip memberikan pengaruh sebesar $21,5 \%$.

Sedangkan perbedaan antara penelitian ini dengan penelitian terdahulu Kusnida, Mulyani \& Su'udi, (2015) terletak dalam pengambilan sampel penelitian. Yaitu menggunakan teknik Purposive Sampling sedangkan penelitian ini menggunakan teknik Sampling Jenuh. Selain itu juga terdapat perbedaan yang mendasar yaitu perbedaaan objek penelitan dan periode pengamatan antara keduanya. yaitu di tahun 2015 dengan objek penelitian pada kelas VII SMP pada hasil belajar menulis cerpen sedangkan penelitian ini dilakukan pada tahun 2021 dengan objek penelitian hasil belajar pada akuntansi keuangan.

\section{Perbedaan Peningkatan Hasil Belajar Siswa yang Media Film dokumenter dengan Hasil Belajar Siswa yang Menggunakan Media Komik Foto pada pengukuran akhir (posttest).}

Perbedaan hasil belajar siswa yang menggunakan Media film Dokumenter lebih besar dibandingkan hasil belajar siswa yang mengunakan Media Komik Foto pada pengukuran akhir (posttest). Hal tersebut tergambarkan dari hasil rata-rata nilai yang di peroleh siswa pada pengukuran akhir (posttest) kelas eksperimen sebesar 83.19 dengan N-Gain sebesar 0.69 berkategori sedang dan pengukuran akhir (posttest) di kelas kontrol sebesar 76.05 dengan N-Gain sebesar 0.53 berkategori sedang. Dengan demikian, nilai rata-rata pada pengukuran akhir di kelas eksperimen lebih besar dibandikan dengan nilai rata-rata di kelas kontrol. Artinya Media Film 
Dokumenter lebih unggul dan dapat meningkatkan hasil belajar siswa dibandingkan dengan Media Komik Foto. Hal ini sesuai dengan keunggulan dari media film dokumenter yaitu film dapat nilai-nilai positif daan mengundang pemikiran dan pembahasan dalam kelompok siswa, bahakan film dapat membawa dunia kedalam kelas.

Hal ini sesuai dengan pendapat Arsyad (dalam Lanti, 2017) film dan video mempunyai beberapa kelebihan yaitu:

a. Dapat melengkapi pengalaman-pengalaman siswa ketika membaca, bediskusi, berpraktik, dan lain-lain

b. Dapat menggambarkan suatu proses secara tepat yang dapat disaksikan secara berulang-ulang

c. Disamping mendorong dan mengingatkan motivasi, film dan video menanamkan sikap dan segisegi efektif lainnya.

d. Film dan video yang mengandung nilai-nilai positif dan mengundang pemikiran dan pembahasan dalam kelompok siswa. Bahkan, film dan video dapat membawa dunia ke dalam kelas.

e. Dapat menayajikan peristiwa yang berbahaya bila dilihat secara langsung seperti lahar gunung berapi atau perilaku binatang buas.

f. Film dan video dapat di pertunjukan kepada kelompok besar atau kelompok kecil, kelompok heterogen, maupun perorangan.

g. Teknik pengambilan gambar frame demi frame, film yang dalam kecepatan memakan waktu satu minggu dapat ditampilkan dalam waktu dua menit.

Hasil pengujian ini sejalan dengan penelitian terdahulu, hasil penelitian yang dilakukan oleh (Agustina, Suyatna \& Suyanto, 2017) yaitu perbandingan hasil belajar siswa menggunakan media gambar bergerak dengan gambar diam. Dengan hasil penelitian pada kelas gambar bergerak diperoleh rata-rata posttest 69,13 dan $\mathrm{N}$-gain 0,64 dengan kategori sedang, lebih besar dari pada hasil belajar kelas bergambar diam dengan rata-rata posttest 53,3 dan $\mathrm{N}$-gain 0,48 dengan kategori sedang.

Sedangkan perbedaan antara penelitian ini dengan penelitian terdahulu (Agustina, Suyatna \& Suyanto, 2017) terletak pada metode yang digunakan, yaitu menggunakan uji mann whitney, sedangkan pada penelitian ini menggunakan uji $t$, dalam pengambilan sampel penelitian menggunakan teknik cluster random sampling sedangkan penelitian ini menggunakan teknik Sampling Jenuh. selain itu juga terdapat perbedaan yang mendasar antara penelitian keduanya yaitu perbedaaan objek penelitan dan periode pengamatan antara keduanya, melakukan penelitian di tahun 2017 dengan objek penelitian pada kelas XI IPA pada hasil belajar pada fisika sedangkan penelitian ini dilakukan pada tahun 2021 dengan objek penelitian hasil belajar pada akuntansi keuangan.

\section{PENUTUP}

Penelitian ini dilakukan untuk mengetahui apakah Media pembelajaran Film Dokumenter dan Komik Foto di Smk As-Saabiq (Studi Eksperimen Pada Kompetensi Dasar Pencatatan Kartu Utang Di Kelas Xi Akuntansi Keuangan Lembaga). Berdasarkan analisis hasil penelitian yang telah dilakukan, maka dapat di simpulkan bahwa:

1. Terdapat perbedaan hasil belajar siswa pada mata pelajaran akuntansi keuangan materi pencatatan kartu utang di kelas eksperimen sebelum dan sesudah diberi perlakuan dengan menggunakan media pembelajaran film dokumenter. Memperoleh peningkatan yang cukup baik (signifikan) dengan N-Gain kategori sedang.

2. Terdapat perbedaan hasil belajar siswa pada mata pelajaran akuntansi keuangan materi pencatatan kartu utang di kelas kontrol sebelum dan sesudah diberi perlakuan dengan menggunakan media pembelajaran komik foto. Memperoleh peningkatan yang cukup (signifikan) dengan N-Gain kategori sedang. 
3. Terdapat perbedaan hasil belajar siswa padapengukuran akhir (Posttest) di kelas eksperimen yang menggunakan media film dokumenter dengan kelas kontrol yang menggunakan media komik foto pada mata pelajaran Akuntansi Keuangan di SMK As-Saabiq.

\section{REKOMENDASI}

Berdasarkan kesimpulan dari hasil penelitian yang telah diuraikan sebelumnya maka peneliti menyampaikan rekomendasi sebagai berikut:

1. Media Film Dokumenter

Media pembelajaran film dokumenter dapat meningkatkan hasil belajar secara signifikan. Oleh karena itu, hendaknya dapat diterapkan ke dalam pembelajaran akuntansi keuangan sehingga dapat digunakan sebagai salah satu alternatif dalam pembelajaran.

2. Media Komik Foto

Media pembelajaran komik foto dapat meningkatkan hasil belajar secara signifikan. Oleh karena itu, hendaknya dapat diterapkan ke dalam pembelajaran akuntansi keuangan sehingga dapat digunakan sebagai salah satu alternatif dalam pembelajaran.

3. Bagi peneliti selanjutnya, dapat di jadikan referensi untuk penelitian lebih lanjut mengenai penerapan media film dokumenter dan media komik foto supaya dapat memperkuat hasil penelitian terutama dalam mata pelajaran lain, dan dapat mengkombinasikan media pembelajaran yang lain serta membandingkan hasil dari penelitian tersebut.

\section{DAFTAR PUSTAKA}

Agustina, D., Suyatna, A., \& Suyanto, E. (2017). Perbandingan Hasil Belajar Siswa Menggunakan Media Gambar Bergerak Dengan Gambar Diam. Jurnal Pembelajaran Fisika, 5(3), 25-34.

Agustiany, R., Hardi, E., \& Ilmiati (2021). Perbedaan Hasil Belajar Kognitif Siswa Melalui Penggunaan Media Audio Visual dan Media Peta Konsep pada Materi Ekosistem. J-KIP (Jurnal Keguruan dan IImu Pendidikan), 2(1), 15-20.

Aryansyah, F. (2021). Pelaksanaan Question Student Have Method Dalam Meningkatkan Hasil Belajar Pada Mata Pelajaran Ekonomi di SMA. J-KIP (Jurnal Keguruan dan IImu Pendidikan), 2 (1), 91-98.

Indriana, D. (2011). Ragam Alat Bantu Media Pengajaran. Jogjakarta: Diva Press

Kusnida, F., Mulyani, M., \& Su'udi, A. (2015). Keefektifan Penggunaan Media Audiovisual dan Media Komik Strip dalam Pembelajaran Menulis Cerpen yang Bermuatan Nilai-nilai Karakter Berdasarkan Gaya Belajar. SELOKA. Vol. 4(2) 111-117.

Lanti, E. (2017). Media Pengembangan Pendidikan Karakter Bagi Siswa Sekolah Dasar. Gorontalo: Athra Samudra.

Laurent, D. A. (2018). Pengembangan Media Komik Bermuatan Pendidikan Karakter. Skripsi Pada Program Studi Pendidikan Ekonomi, Universitas Sanata Dharma Yogyakarta.

Molstad, C. E., \& Karseth, B. (2016). National Curricula in Noeway and Finland: The Role of Learning Outcomes European Educational Research Journal, 15 (3), 329-433.

Nurhasanah, S. (2016). Minat Belajar Sebagai Determinasi Hasil Belajar Siswa. Jurnal Pendidikan Manajemen Perkantoran. (Online), Vol.1 No.1. 
Putro, S. S., \& Tuasikal, A. R. S. (2018). Implementasi Media Audiovisual (Video) Dan Media Gambar (Poster) Terhadap Hasil Belajar Shooting Bolabasket. Jurnal Pendidikan Olahraga dan Kesehatan, 06(02), 477-481.

Sudjana. (2012). Penilaian Hasil Proses Belajar Mengajar. Bandung: Remaja Rosdakarya.

Sugiyono. (2015). Metode penelitian kombinasi (mixed methods). Bandung: Alfabeta.

Sugiyono. (2016). Metode Penelitian Pendidikan. Bandung: Alfabeta. 
